\title{
Perifériás érbetegség modern kezelési szempontjai
}

\author{
Simon Éva \\ Korona Prevent Med, Sopron \\ Levelezési cím: Dr. Simon Éva, PhD, e-mail: sopron.esimon@gmail.com
}

Az alsó végtag perifériás érbetegség (Lower Extremity Peripheral Artery Disease; LEPAD) az iparilag fejlettebb országokban egyre gyakrabban fordul elő, korunk egyik leggyakoribb betegségének, az érelmeszesedésnek jellegzetes megjelenési formája. Fontos, hogy a szív és agyi erek vizsgálata mellett az alsó végtagi érszükület diagnosztikája, kezelése és rehabilitációja ma már egyenrangú része legyen a kardiovaszkuláris prevenció és rehabilitáció szerteágazó feladatának. Ezen betegségek kialakulásának folyamata azonos. Míg korábban a betegség csak a klinikai tünetek, a típusosan fellépő terhelésre jelentkező végtagfájdalom és szövődményeinek megjelenése után került a figyelem középpontjába, addig jelenleg elöremutató szemléletváltás kibontakozásának lehetünk részesei. Nagyon egyszerủ módon kivitelezhető szürővizsgálatok felhívják a figyelmet a betegség gyakoriságára. Ha gondolunk rá és keressük a figyelmeztető jeleket, egyértelművé válik számunkra, hogy lényegesen gyakoribb és nagyobb jelentőségü betegségről van szó, mint korábban gondoltuk. Kiemelt cél az időben történő felismerés és kezelés, amelyek segítségével megelőzhető a szomorú végkifejlet, a végtagvesztés, amely a beteg életminőségét a lehető legnagyobb mértékben negatív módon befolyásolja. Külön figyelmet szükséges fordítani cukorbetegek esetében a megjelenésére, mert az alsó végtagi vérellátási hiány rendkívül nagymértékben fokozza az alsó végtagi fekélyképződés kialakulását.

Kulcsszavak: perifériás érbetegség, kardiovaszkuláris prevenció, kardiovaszkuláris rehabilitáció, alsó végtag revaszkularizáció

\section{Optimal Treatment of Lower Extremity Peripheral Artery Disease}

The Lower Extremity Peripheral Arterial Disease (LEPAD) is an increasingly common occurrence in more developed industrial countries, and a typical form of arteriosclerosis, which is one of the most common diseases of our age. It is imperative for the diagnostics, treatment and rehabilitation of lower extremity arteriosclerosis to be treated as an equally important part of the multi-faceted task posed by cardiovascular prevention and rehabilitation. The development process of these diseases is identical. Although the disease used to catch attention only after the appearance of its clinical symptoms (the typically appearing stress-induced extremity pain and its complications), we are currently witnessing the evolution of a progressive paradigm shift. Effortless screening tests raise public attention to the prevalence of the disease. When contemplating the disease and looking for its warning signals, it will become obvious that its frequency and importance substantially exceed those hitherto attributed to it. Timely diagnosis and treatment are distinguished objectives, as they might help avert the unpleasant outcome, the loss of limbs, which influences the patient's quality of life in the most negative way possible. The presence of the disease in diabetic patients deserves special attention, as the lacking blood supply in lower extremities massively facilitates the appearance of lower extremity ulcers.

Keywords: peripheral arterial disease, cardiovascular prevention, cardiovascular rehabilitation, lower extremity revascularization 


\section{Epidemiológiai adlatok és kockázati tényezők}

Az alsó végtag perifériás érbetegség (Lower Extremity Peripheral Artery Disease; LEPAD) előfordulása világszerte nem ismert pontosan, az Egyesült Államokban 8-12 millióra teszik a megbetegedések számát, míg világszerte mintegy 202 millió a megbetegedések száma (1). Az előfordulása egyértelmű összefüggést mutat az életkor növekedésével. Míg az általános előfordulási gyakoriság 4,6\%-os 2381 amerikai beteg vizsgálata során, addig 40 és 49 év között $0,9 \%, 50$ és 59 év között 2,5\%, 60 és 69 év között 4,7\%, de 69 év felett ez a szám már $14,5 \%$ (2). Az utóbbi évtizedek adatai alapján világszerte további prevalencia-növekedés várható, ahogy növekszik a dohányzók, cukorbetegek, magas vérnyomásos, ülö életmódot folytató és túlsúlyos személyek száma. Klinikai vizsgálatok igazolják, hogy a diabétesz 1,9-4,0-szer nagyobb kockázatot jelentett alsó végtagi érszükület kialakulásához (3). A rizikófaktorok megegyeznek a koronária- és agyérbetegség kockázati tényezőivel. Nem elhanyagolható a krónikus veseelégtelenség, az emelkedett gyulladásos faktorok szerepe sem. Az egyes kóroki tényezők külön szakterületeken való kezelése ellenére tudnunk kell, hogy egyiknek sincs kiemelt szerepe a többivel szemben.

\section{Diagnózis felállítása}

Korábban csak a claudicatio intermittens tünetegyüttesét, a pihenésre megszünő lábikragörcsöt tekintettük a klinikai diagnózis alapjának. Ma már tudjuk, hogy sok "atípusos" panasz hátterében is ez a betegség állhat. llyenek a pihenésre enyhülö fáradt láb, comb- és farfájdalom, különböző lokalizációjú izomgörcsök. Más betegségek mellet párhuzamosan vannak jelen a tünetek és nem magyarázhatjuk azokat csupán neuropathiával, arthrosissal, arthritisszel, lumbalis spinál szükülettel, Baker-cisztával. Számos népességalapú vizsgálat igazolja, hogy a panaszos és panaszmentes perifériás érbetegség aránya 1:3 (4).

A perifériás erek egyszerủ tapintási vizsgálatát követően a könnyen és olcsón kivitelezhető boka-kar index mérése az elsődleges diagnosztikai tevékenység. 0,9-nél alacsonyabb érték a betegségre vonatkozóan magas szenzitivitást és specificitást jelez, ha a jelenleg arany standardnak számító invazív arteriográfiával vetjük össze. Fontos tudni, hogy a boka-kar index meghatározásán alapuló diagnózis felállításakor a diabétesz 3-4-szeresre növeli az álnegatív eredmény kockázatát. Ennek magyarázata, hogy a hosszabb ideje fennálló diabétesz esetén kialakuló, az artériák falára lokalizálódó kalcifikáció miatt a lábszár artériák a mérés során nem komprimálhatók, így a boka magasságában a valódi nyomásnál jóval magasabb értéket mérhetünk. A nem komprimálható erek miatt a vizsgálat értékelhetetlen, vagy 1,4-nél nagyobb index elfedheti, maszkírozhatja a fennálló érszükületet
(5). Angiológiai központokban, illetve szakrendeléseken elérhető további diagnosztikai tesztek állnak rendelkezésre a diagnózis finomítására, amelyeket speciálisan kiképzett személyzet speciális eszközökkel el tud végezni. Ilyen lehetőség a folyamatos hullámú Doppler (CWD) vizsgálat során nyert pulzushullám további elemzése, valamint a fotopletizmográfia. További pontosabb elemzést tesz lehetővé az öregujj artériás nyomásának meghatározása és azt az értéket felhasználó öreguij-kar nyomásindex (TBI) számolása. A diagnosztikus TBI-határérték 0,6-0,7 között van, ami alatt az érszükület valószínüsíthető. Az alsó végtagi artériás perfúzió zavarának mérésére hatékony eszköz lehet a bőr-oxigenizáció vizsgálata. A transzkután oxigén parciális nyomásának vizsgálata (TcPO2) különösen fekélyképződés esetén indokolt. Segít annak eldöntésében, hogy hagyományos kezelés mellett várható-e a fekélyképződés gyógyulása, vagy az elörehaladott iszkémia miatt valamilyen típusú revaszkularizáció a gyógyulás előfeltétele. 50 Hgmm-nél nagyobb érték esetén jó a prognózis, 30 Hgmm alatt csekély az esély a sebgyógyulásra revaszkularizáció nélkül. A képalkotó eljárások - mint CT-angiográfia, MR-angiográfia, DSA - a szükségesnek ítélt revaszkularizáció típusának (érsebészeti vagy endovaszkuláris) tervezésében segítenek. A speciális diagnosztikai módszerek különösen a diabéteszes láb iszkémiás eredetének tisztázását segítik, amelynek kialakulásáért a diabeteses neuropathia mellett a végtagot ellátó nagy artériák keringésének károsodása, a kiserek áramlási rendellenességei, csont és ízületeltérések, infekciók változó arányú jelenléte tehető felelőssé (6).

\section{Tünetmentes perifériás érbetegség kezelése}

Szív- és/vagy agyi érelmeszesedés klinikai tüneteinek megjelenése esetén, illetve halmozott rizikójú személyeknél a rizikóbecslés fontos részeként keresnünk kell az alsó végtagi érintettséget. A megelőző stratégia alkalmazása a legfontosabb ebben az esetben. Az érelmeszesedés folyamatának a lassítása, megállitása a fő cél. Számos tanulmány bizonyította, hogy ez a legmegfelelőbb eljárás ezeknél a betegeknél.

\section{Dohányzásleszokás támogatása}

A perifériás érbetegség súlyossága statisztikai elemzések alapján egyenes arányban van dohányzás mértékével (7). Nagyszámú perifériás érbetegségben szenvedő betegnél - ahol 27\%-ban nem volt végtagfájdalom (claudicatio intermittens) - kimutatták, hogy a dohányzás elhagyására és a rendszeres tréningprogram folytatásának hatására szignifikáns mértékben javult a járás távolság.

\section{Antitrombitikus terápia}

Nem bizonyított, hogy tünetmentes betegeknél kedvező hatása lenne ennek a terápiának. Abban az esetben 
szükséges alkalmazni, ha egyéb vaszkuláris társbetegségek miatt szükség van rá.

\section{Statinterápia}

Számos vizsgálat történt annak elemzésére, hogy a statinterápia milyen hatással van a betegség kimenetelére. Bizonyítást nyert a statinkezelés protektív hatása a tünet nélküli perifériás érbetegek mortalitására és kardiovaszkuláris eseményeik számára vonatkozóan (8).

\section{Fizikai tréning és a láb funkciója}

Alsó végtagi diszkomfort tünetek nélkül is kimutatható ezen betegeknél a lassúbb gyaloglási sebesség, roszszabb egyensúlyozó képesség és más negatív funkcionális hatás.

A tünetmentes betegek 26\%-ánál egy év múlva megjelenik a klaudikáció és különösen a diabéteszes betegeknél ekkor már jelentős alsó végtagi iszkémia lehet jelen (9).

\section{Claudicatio intermittens kezelése, szekunder prevenció}

A terhelésre jelentkező lábikragörcs az alsó végtagi érszükület leggyakoribb megjelenési formája. Számos kísérőbetegség módosíthatja a tüneteket, ezért nagyon fontos az egyénre szabott terápia tervezése. Kiemelkedő jelentősége van ebben az időszakban a betegoktatásnak, életmód-változtatásnak, megfelelő gyógyszeres terápiának az életminőség javítása érdekében. A szekunder prevenció lehetőségei megegyeznek kardiovaszkuláris betegségben, az agyi erek betegségében és alsó végtagi érszükületben.

\section{Dohányzásleszokás támogatása}

Követéses vizsgálatok bizonyították, hogy a tovább dohányzóknál magasabb arányban történt amputáció, halál és szívinfarktus, mint azok között, akik abbahagyták a dohányzást. Hasonlóan két-háromszor nagyobb a bypass graft elzáródások száma a tovább dohányzók között (10).

\section{Dyslipidaemia}

A 2016-os ESC/EAS ajánlás elsődleges célnak az LDL-koleszterin szintjének csökkentését javasolja. Nagyon magas rizikó esetén az LDL-szint 1,8 mmol// alá csökkentése vagy minimum $50 \%$-os redukció elérése javasolt akkor, ha a kiindulási érték 2,6-3,5 mmol/l. Magas rizikó esetén az LDL-szint 2,6 mmol// alá csökkentése vagy 2,6-5,2 mmol/l kiindulási értéknél 50\%-os redukció a cél. Alacsony vagy közepes rizikó esetén 3,0 $\mathrm{mmol} / \mathrm{l}$ az elérendő cél. HDL-koleszterinre nincs egyértelmúen meghatározott célérték, de férfiakban 1,0 $\mathrm{mmol} / \mathrm{l}$, nőknél 1,2 mmol/l feletti érték esetén csökken a kardiovaszkuláris rizikó. Szérum trigliceridre vonat- kozóan nem határoz meg az ajánlás célértéket, de 1,7 mmol/l alatti értéknél alacsonyabb a kardiovaszkuláris rizikó. Az étrendi megfontolásokon túl a statinok, ezetimid és evolocumab adását javasolja az ajánlás (11).

\section{Diabetes mellitus}

Cukorbetegségben az alsó végtagi érszűkület patológiai megjelenésében különbözik összehasonlítva a cukorbetegségben nem szenvedőkkel. Jellemző az infrapopliteális érrendszer fokozott érintettsége, a diffúz megjelenés, hosszabb szakaszokat érintő elzáródás, az artériafal médiarétegének gyakori kalcifikációja és a szegényes kollaterális keringés. A nagyerek elváltozásaihoz gyakran társul a mikrocirkuláció zavara. A gyakori neuropathia is nehezíti a keringészavar korai klinikai felismerését (6).

A cukorbetegségben szenvedő betegek legalább 29\%ánál észlelhető perifériás érbetegség. Nem ismert, hogy az cukorbetegség agresszív kezelése milyen előnyökkel jár. Azt azonban tudjuk egy vizsgálatból, hogy az amputációs ráta legalább ötször nagyobb, mint nem cukorbetegeknél. Ugyanebben a populációban a cukorbetegek halálozásának kockázata háromszoros összehasonlítva a nem cukorbetegekével (12).

\section{Magas vérnyomás}

Nagyon szoros összefüggés van a kardiovaszkuláris betegségek és a magas vérnyomás között, természetesen beleértve az alsó végtagi érszükületet is. A megfelelő terápia csökkenti a kardiovaszkuláris eseményeket, mint szívinfarktus, szívelégtelenség, stroke, halál. Nincsenek bizonyítékok arra, hogy a béta-blokkolók adása rontaná a klaudikációs panaszokat. Az angiotenzin konvertáló enzim inhibitorok pedig balkamra-diszfunkció esetén csökkentik a kardiovaszkuláris események számát (8).

\section{Trombocitaaggregáció-gátlás és egyéb antitrombotikus terápia}

Számos tanulmány bizonyítja az aszpirin kedvező hatását. A javasolt dózis napi 75 mg és 325 mg között van. Az Érsebészeti Társaság legfrissebb ajánlásában az ajánlási osztály I, az evidenciaszint A. Napi 75 mg clopidogrel az aszpirin hatékony alternatívájaként szintén javasolt. $A z$ ajánlási osztály $A$, evidenciaszint $B$. Arra nincsenek evidenciák, hogy a warfarin önmagában kedvező lenne perifériás érbetegségben (13).

\section{Gyógyszeres terápia a végtagfunkció javítására}

A járástávolság javítására jelenleg több gyógyszer áll rendelkezésre. 1984 óta van forgalomban a pentoxifyllin. A vérviszkozitás csökkentésén, a trombocita-aggregáció gátlásán keresztül javítja a véráramlást, az érintett régióban javítja a szöveti oxigenizációt. 
A cilosztazol később jelent meg a gyógyszerpiacon. Foszfodiészteráz-gátló tulajdonságán keresztül gátolja a trombocita-aggregációt és direkt vazodilatátor hatással is rendelkezik.

2013 óta az amerikai és európai ajánlásokban I. ajánlási osztály A-szintű evidenciával napi $1 \times 100$ mg cilosztazol adása szívelégtelenségben nem szenvedő betegeknek a fájdalommentes járástávolság javítására (14). 3 hónapos próbaidő után javasolják az eredményesség mérlegelését. Akut szívinfarktusban adása ellenjavallt. Napi 3×400 mg pentoxifillin csak azoknak a betegeknek indokolt, akiknek kontraindikált, vagy nem tolerálják a cilosztazolt (13).

\section{Klinikai vizsgálatokat végeztek \\ trimetazidinnel}

A trimetazidin az ún. 3-KAT-inhibitorok első képviselője. Antiiszkémiás hatást fejt ki anélkül, hogy hemodinamikai változást okozna. Hatásmechanizmusa: szelektíven gátolja a mitokondriumokban a zsírsavak béta-oxidációjához szükséges 3-keto-acil-CoA-tioláz enzimet Ennek eredményeképpen az energiatermelés a zsírsavak béta oxidációja helyett a hatékonyabb glükóz-oxidációval történik. 72 beteget konvencionális terápiában részesítettek és random szerint két csoportra osztottak. 6 hónapos terápia után a trimetazidin csoportban szignifikánsan javultak a klinikai tünetek, növekedett a járástávolság, a fájdalom később kezdődött. A boka-kar index nem változott (15).

\section{Fizikai aktivitás, mint a gyógyítás sarokkőve}

Több mint 40 éve egyértelmúen bebizonyították a klinikai vizsgálatok, hogy a rizikófaktorok csökkentése, valamint ülő életmód helyett a fizikai aktivitás az egyik legjobb gyógymód az alsó végtagi érszűkület progressziójának megakadályozására. 1200 beteg adatainak metaanalízise mutatta, hogy a járásképesség 50-200\%-kal növekedett fizikai aktivitás hatására a hagyományos maximális gyógyszeres terápia mellett (16). Ez évek óta I. ajánlási osztály A-szintű evidenciával (13). Bizonyítást nyert az is, hogy a tréningprogram akkor a leghatékonyabb, ha legalább folyamatosan 6 hónapig tart, hetente legalább 3 alkalommal és egy foglalkozás legalább 30 percig tart, lehetőség szerint a maximális végtagfájdalomig, mint végpontig (17). Mégis szükséges felhívni rá a figyelmet, mert ezzel kapcsolatos elsődleges feladat a beteg együttmüködésének megnyerése, a motiváció fenntartása és párhuzamosan figyelmet kell fordítani a szekunder prevenció nem gyógyszeres és gyógyszeres lehetőségeinek együttes alkalmazására, ide értve az aszpirin- és statinterápiát. A beteg állapotától függően szükséges lehet invazív beavatkozás elvégzése: angioplasztika, stentimplantáció, bypass-mútétek. A funkcionális kapacitás felmérésére a tréning elkezdése előtt és a folyamat követésére szükséges a treadmill járásteszt, vagy legalább a 6 perces járásteszt végzése. Ezzel meghatározható az alsó végtagok funkcionális kapacitása: a fájdalom kezdetéig mért járástávolság és a maximális járástávolság, amelyet a beteg fokozódó fájdalma ellenére képes megtenni.

A mozgás nem feltétlenül javítja a beteg boka-kar indexét, azonban kedvezően hat a meglévő kollaterális hálózatra, indukálja az angiogenezist, emeli a nitrogén-oxid-szintet, kedvezően befolyásolja a mikrocirkulációt, javítja a vázizomzat biomechanikáját és a hemoreológiai paramétereket.

\section{Az ajánlott mozgás formája, időtartama és intenzitása}

A tréningprogram nemcsak gyaloglás lehet, hanem bármilyen mozgásforma, amit a beteg hajlandó végezni. Ide tartozhat a kerékpár, lépcsőn járás, lábujjhegyen járás, tánc, aerobik, statikus és dinamikus lábgyakorlatok stb. Az intervallum tréning és a folyamatos tréning egyaránt alkalmas arra, hogy a beteg a maximális fájdalom közelében tréningezzen.

A felügyelt tréning a leghatékonyabb, ha összehasonlítjuk az otthon végzett tréninggel, vagy a beteg napi tevékenysége során végzett gyaloglással. Az otthoni tréning hatásfokát jelentősen javíthatja a rendszeres kapcsolat (telefon, e-mail, egyéb telekommunikációs eszközök) a beteg és a szakszemélyzet között.

Nagyon fontos lenne legalább 26 hétig részt venni a programokon, de a legtöbb vizsgálat azt mutatja, hogy a betegek lemorzsolódnak, még akkor is, ha egyértelmüen javul az életminőségük. Egy vizsgálatban 102 beteg közül csak $47 \%$ fejezte be a programot (18).

A CLEVER-vizsgálat 2012-ben azt az eredményt mutatta 112 vizsgált betegen, hogy aorto-iliacalis szűkület esetén optimális gyógyszeres terápia mellett a fizikai tréningben részesült betegek járástávolsága hosszabb volt a tréningprogram végére, mint a stentimplantációban részesült betegeké, ugyanakkor mindkét csoportban szignifikánsan jobbak voltak az eredmények, mint a „csupán” optimális gyógyszeres terápiában részesülőké (19).

\section{Alsó végtagi revaszkularizáció}

Ismert, hogy a perifériás érbetegség lassú progressziójú, viszonylag benignus lefolyású betegség. A rendelkezésre álló terápiás eszközök segítségével megelőzhető, vagy legalábbis időben kitolható a legrettegettebb szövődmény, a végtag-amputáció.

A betegek követése nagyon fontos, szükséges a legalább évenkénti ellenőrzés, amelynek ki kell terjednie a dohányzás, fizikai tréning, egyéb rizikótényezők ellenőrzésére, valamint legalább boka-kar index mérésére, 
amely képes megmutatni a betegség progresszióját (8). Az alsó végtagi keringés helyreállítása, a revaszkularizáció akkor indokolt, ha a járás korlátozott mértéke a beteg életminőségét jelentősen rontja, vagy kritikus végtagi iszkémia alakul ki és a végtag életképessége kérdésessé válik. Egyre több érsebészeti centrum áll rendelkezésre, ahol a revaszkularizáció szükségességének elbírálása megtörténik. A döntéseket a beteg, szükség szerint hozzátartozója bevonásával jól szervezett teammunka eredményeként kell meghozni. Érsebész, intervenciós radiológus, belgyógyász, rehabilitációban jártas kardiológus, gyógytornász, pszichológus, társbetegségek esetén diabetológus, nefrológus, neurológus, bőrgyógyász, reumatológus összetett szempontrendszer átgondolásával vesz részt a döntési folyamatban. A revaszkularizáció optimális kivitelezésének alapfeltétele a megfelelő időzítés, a beavatkozás módjának gondos mérlegelése és a későbbi beteggondozás.

Külön figyelmet kell fordítani a cukorbetegek ellátására, mert náluk más a tünetek megjelenése és a keringési zavar kimutatása a nem cukorbetegekkel összevetve nehézségekbe ütközhet. A lábszárfekélyek megjelenésében nagyon magas a vérellátási hiány komponens, ezért minden diabéteszes beteg alsó végtagi fekélye mindaddig artériás eredetűnek tekintendő, amíg ennek ellenkezője nem bizonyított (6).

A nemzetközi ajánlások szerint minden koronáriabetegnél és szívelégtelenségben szenvedő betegnél a rizikó-stratifikáció részeként szükséges a boka-kar index vizsgálat elvégzése, gondolni kell az alsó végtagi perifériás érbetegség lehetőségére. A beteg életminőségét jelentősen korlátozó fájdalom esetén pedig szükség van az időben végzett endovaszkuláris terápiára vagy érsebészeti beavatkozásra, amennyiben a gyógyszeres terápia a tréningprogrammal együtt sikertelen volt és jó esély van a tünetek javulására, illetve a várható javulás meghaladja a beavatkozás kockázatát. Fontos szempont még, hogy a beavatkozás kedvező hatása várhatóan legalább két évig fennálljon (20).

\section{Ko̊vetkeztetések}

A perifériás érbetegség egyre gyakoribb megbetegedés a fejlettebb társadalmakban, epidemiológiai adatok alapján várhatóan tovább növekszik a lakosság érintettsége. Halmozott megjelenése összefüggésben van az egészségtelen életviteli és táplálkozási szokásokkal, az ülő életmód elterjedésével és nem utolsósorban a várható élettartam növekedésével. Kiemelten fontos kockázati tényező, amely jelentősen rontja az életminőséget és rettegett szövődménye a végtagvesztés. Rendelkezésre állnak azok az egyszerüen kivitelezhető módszerek, amelyekkel még a tünetek megjelenése előtt diagnosztizálhatjuk, ha gondolunk rá. Atípusos megjelenése miatt különös figyelmet kell fordítani cu- korbetegség esetén az időben történő helyes diagnózisra. Viszonylag lassú progressziójú betegség, ami időben elkezdett komplex terápiával sokáig egyensúlyban tartható. A betegek korszerü ellátásában kiemelt jelentősége van a társszakmák együttmüködésének. Az angiológusok, kardiológusok, intervenciós radiológusok és érsebészek alkotta vaszkuláris teamek szerveződése nagyon fontos annak érdekében, hogy a végtag-amputációk minél nagyobb számban elkerülhetők legyenek. Ma már rendelkezésre állnak kiválóan működő munkacsoportok az egyes érsebészeti központokban. Számukat és elérhetőségüket azonban bővíteni szükséges, hogy a rászoruló betegek időben megfelelő ellátásban részesülhessenek. A fekvő- és járóbeteg-rehabilitációs munkacsoportok is felkészülten várják programjaikkal az arra rászoruló betegeket.

\section{Irodalom}

1. Fowkes FG, Rudan D, Aboyans V, et al. Comparison of global estimates of prevalence and risk factors for peripheral artery disease in 2000 and 2010: a systematic review and analysis. Lancet 2013; 382: 1329-40. https://doi.org/10.1016/S0140-6736(13)61249-0

2. Selvin E, Erlinger TP. Prevalence of and Risk Factors for Peripheral Arterial Disease in the United States: Results From the National Health and Nutrition Examination Survey, 19992000. Circulation 2004; 110: 738-43. https://doi.org/10.1016/j. jvs.2004.11.004

3. Thiruvoipati T, Kielhorn CE, Armstrong EJ, et al. Peripheral artery disease in patients with diabetes: Epidemiology, mechanisms, and outcomes. World J Diabetes 2015; 6(7): 961-9. https://doi. org/10.4239/wjd.v6.i7.961

4. Hirsch AT, Criqui, MH, Treat-Jakobson D, et al. Peripheral Arterial Disease Detection, Awareness, and Treatment in Primary Care. JAMA 2001; 286(11): 1317-1324. https://doi.org/0.1001/ jama.286.11.1317

5. Aerden D, Massaad D, von Kemp K, et al. The Ankle-Brachial Index and the Diabetic Foot: A Troublesome Marriage. Ann Vasc Surg 2011; 25(6): 770-777. https://doi.org/10.1016/j.avsg.2010.11.002

6. Kolossváry E, Bánsághi Z, Szabó GV, et al. A diabeteses láb ischaemiás eredete. Epidemiológia, a diagnózis nehézségei, prevenciós és revascularisatiós lehetőségek, Orvosi Hetilap 2017; 158(6): 203-211. https://doi.org/10.1556/650.2017.30656

7. Fowkes FG, Housley E, Riemersma RA, et al. Smoking, Lipids, Glucose Intolerance, and Blood Pressure as Risk Factors for Peripheral Atherosclerosis Compared with Ischemic Heart Disease in the Edinburgh Artery Study. Am J Epidemiol 1992; 135: 331-340. https://books.google.hu/books?isbn=0763746894

8. Stone NJ, Robinson JG, Lichtenstein AH, et al. 2013 ACC/AHA guideline on the treatment of blood cholesterol to reduce atherosclerotic cardiovascular risk in adults: A report of the American College of Cardiology/ American Heart Association Task Force on Practice Guidelines. Circulation 2014; 129(25 Suppl 2): S1-45. https://doi. org/10.1161/01.cir.0000437738.63853.7a

9. McDermott MM, Fried L, Simonsick E, et al. Asymptomatic Peripheral Arterial Disease Is Independently Associated With Impaired Lower Extremity Functionining. The Women's Health and Aging Study. Circulation 2000; 101: 1007-1012. https://doi.org/10.1161/01. CIR.101.9.1007

10. Willigendael EM, MD, Teijink JA, Bartelink ML, et al. Smoking and the patency of lower extremity bypass grafts: A meta-analysis analysis. J Vasc Surg 2005; 42: 67-74. https://doi.org/10.1016/j. jvs.2005.03.024 
11. Catapano AL, Graham I, De Backer G, et al. 2016 ESC/EAS Guidelines for the Management of Dyslipidaemias. The Task Force for the Management of Dyslipidaemias of the European Society of Cardiology (ESC) and European Atherosclerosis Society (EAS) Eur Heart J 2016; 37(39): 2999-3058. https://doi.org/10.1093/eurheartj/ehw272 12. Abola MT, Bhatt DL, Duval $S$, et al. Fate of individuals with ischemic amputations in the REACH Registry: three-year cardiovascular and limb-related outcomes. Atherosclerosis 2012; 221(2) 527-535. http://dx.doi.org/10.1016/j.atherosclerosis.2012.01.002

13. Conta MS, Pompeselli FB, Clair DG, et al. Society for Vascular Surgery practice guidelines for atherosclerotic occlusive disease of the lower extremities: Management of asymptomatic disease and claudication. J Vasc Surg 2015; 61: 2S-41S. https://doi. org/10.1016/j.jvs.2014.12.009

14. Anderson JL, Halperin JL, Albert NM, et al. Management of Patients With Peripheral Artery Disease (Compilation of 2005 and 2011 ACCF/AHA Guideline Recommendations). A Report of the American College of Cardiology Foundation/American Heart Association Task Force on Practice Guidelines. Circulation 2013; 127: 00-00. https:// doi.org/10.1161/CIR.0b013e31828b82aa

15. CHU YS, LI DX, ZHANG M, et al. Trimetazidine hydrochloride as a new treatment for patients with peripheral vascular disease - an exploratory trial. Eur Rev Med Pharmacol Sci 2016; 20: 188-193. Online ISSN: 2284-0729

16. Watson L, Ellis B, Leng GC. Exercise for intermittent claudication. Cochrane Database Syst Rev 2008; 4: CD000990 https://doi. org/10.1002/14651858.CD000990.pub2

17. Gardner AW, Poehlman ET. Exercise Rehabilitation Programs for the Treatment of Claudication Pain. A Meta-analysis. JAMA 1995; 274(12): 975-980. doi:10.1001/jama.1995.03530120067043 18. Mouser MJ, Zlabek JA, Ford CL, et al. Community trial of home-based exercise therapy for intermittent claudication. Vasc Med 2009; 14(2): 103-107. https://doi.org/10.1177/1358863X08098596

19. Murphy TP, Cutlip DE, Regensteiner JG. Supervised Exercise Versus Primary Stenting for Claudication Resulting From Aortoiliac Peripheral Artery Disease. Six-Month Outcomes From the Claudication: Exercise Versus Endoluminal Revascularization (CLEVER) Study. Circulation 2012; 125: 130-139. https://doi.org/10.1161/CIRCULATIONAHA.111.075770

20. Aboyans V, Ricco JB, Bartelink ML, et al. 2017 ESC Guidelines on the Diagnosis and Treatment of Peripheral Arterial Diseases, in collaboration with the European Society for Vascular Surgery (ESVS) Eur Heart J (2017) 00,1-60. https://doi.org/10.1093 / eurheartj/ehx095

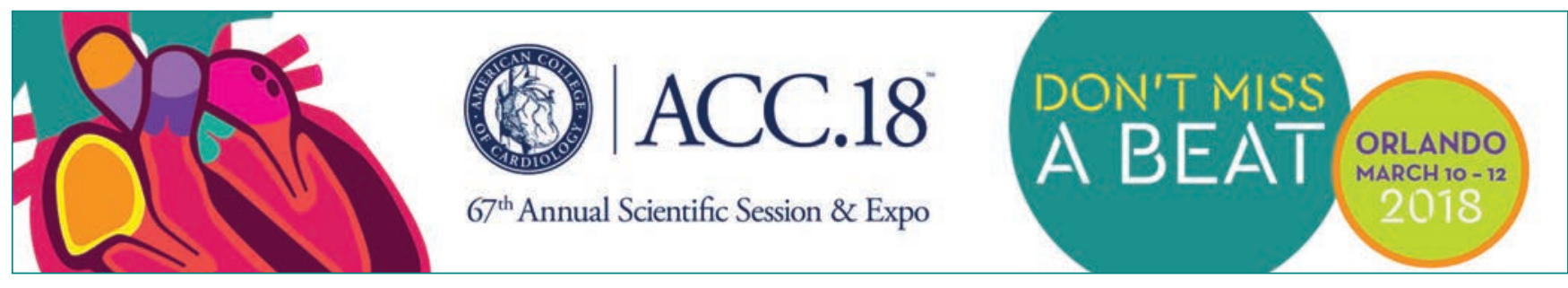

